\title{
Indigenous and postcolonial sociology in South Asia: challenges and possibilities
}

\author{
Siri Gamage \\ School of Social Science and Psychology, Western Sydney University, Parramatta, Australia. \\ Department of Sociology, Faculty of Arts, University of Peradeniya, Peradeniya, Sri Lanka.
}

\begin{abstract}
This paper examines the critical debates and discussions on the Eurocentric nature of sociology in its origin, diffusion, dominance and practice on the one hand and counter discourses that have emerged from disparate groups of sociologists from different parts of the world, on the other. In the process, this paper explores the unequal nature of global knowledge discourse and its impact on the sociology debates and practice in the global periphery with a focus on South Asia. The work of several sociologists who have contributed to the discourses on postcolonial theory and sociology, alternative, indigenous and pluralist sociology, are reviewed with a view to highlighting the predicament of conventional metropolitan sociology as it is practised in the colonised periphery. Ideas for a fresh sociological imagination consonant with indigenous intellectual traditions in South Asia are discussed along with the need to retool methodology. Usefulness of new approaches such as relational and connected sociologies and Southern Theory are discussed. Several approaches and strategies that sociologists in the region can utilise in formulating a knowledge field that is integral with the needs of the people and consonant with their own intellectual or knowledge traditions are also surveyed. The need to go beyond essentialist binaries constructed by imperial/colonial sociology is emphasised along with the need for forming epistemic communities in centres of learning with a view to examine emerging proposals from critical sociologists for a new sociology imagination rooted in the South Asian context.
\end{abstract}

Keywords: Indigenous sociology, postcolonial sociology, Eurocentrism in sociology, Southern Theory, sociology in South Asia.

\section{INTRODUCTION}

Sociology invokes a set of assumptions, concepts, theories, rationale and methodological tools. They emerged in a certain historical, political, economic and cultural context in which imperial-colonial relations were a critical factor. However, in the arguments, theorisations, and assumptions governing sociology and sociological thinking, Western sociologists did not acknowledge the importance of imperial-colonial relations in the emergence and growth of sociology as a discipline or a practice. Instead, they elided this relationship in their imaginations and writings. For example, this is visible in writings about the emergence and spread of modernity. Mainstream Western sociological imagination and theorisations are criticised by sociologists writing from a postcolonial perspective on grounds of Eurocentrism. They also criticise conventional mainstream Western sociology for its universalist tendency, which means that the knowledge, epistemology and methodology so emerged in Europe are presented as universally applicable though they emerged in a particular context.

Thus, these sociologists critical of Eurocentric sociology argue that the way historical sociology is approached also has to change. Moreover, they argue that the sociologists, particularly in the former colonies, need to construct a different sociological imagination

"Corresponding author (gamage.siri@yahoo.com; (DD https://orcid.org/0000-0003-2503-8585 ) 
while selectively using Eurocentric sociological concepts, theories and methods or even modifying and adapting them to the particular contexts of such colonies. As Bhambra (2007; 2016), Go $(2007 ; 2016)$ and others have stated, from a postcolonial or de-colonial point of view, contemporary sociologists need to address these limitations, biases and methodological fault lines. To address the inadequacies within standard sociological paradigms, it is needed to reconfigure understandings of concepts and theories in sociology and the tools employed, e.g. modern vs. non-modern.

According to Go (2013),

"the political decolonization of Asia and Africa in the twentieth century or in other parts of the world was a monumental disappointment. It did not bring a decolonization of consciousness or culture" (Go, 2013; p. 30).

Rather inequalities between the global South and the North continue. Therefore, Go (2013: p. 31) argues that "different sorts of knowledge must be produced to help decolonize consciousness". He refers to an intellectual revolution taking place against provinciality of social sciences.

"The premise of this revolution is that disciplinary sociology's concerns, categories and theories have been formulated, forged, and enacted within Anglo-European metropoles in the interest of those metropolitan societies, and so a new "global sociology" that transcends this provinciality is necessary" (Go, 2016: p. 1).

He expands on the postcolonial critique of provinciality of social sciences and what he terms as Southern Standpoint (see Go, 2016).

Sociologists such as Connell (2007; 2014; 2017) and Santos (2014) want to understand the Western/ Metropolitan hegemony exercised in social sciences by the global social science powers resulting in a pattern of epistemological hierarchy/inequality and develop one's own knowledge, theories, methodologies to counter this hegemony on one hand and produce relevant knowledge and self-understanding of one's own societies, culture, place and peoples on the other. Gunaratne (2010) argues that conducting empirical research based on the reductionist theoretical framework of 'old science' is unlikely to dismantle the vertical disparity and the unequal distribution of labor between social scientists in the West and the East. While keeping that context in mind, scholars in the non-West could engage in alternative discourses at different levels: some focusing on indigenisation, some on endogenisation, some on decolonisation and some on globalization. However,

"A mere recognition of the matrix of power that has organised global divisions is no substitute for the collective quest of indigeneity in individual national traditions. Equally, the presence of the various voices and the plurality of traditions do not automatically render any search for indigeneity precarious and culturally hegemonic" (Thakur, 2015: p.117).

The need for overcoming the binaries constructed by colonialist-modernist discourses in contemporary sociology practice has been proposed for alternative sociologies by several sociologists. Patel (2006; 2010a), for instance, proposes sociologists to critically examine the relationship between power and sociology knowledge while paying close attention to the continuation of colonial binaries reconstructed under globalisation to maintain power-knowledge structure. She calls for a new sociological imagination. Petras has used the concept of imperialism to look at the manifold relationships generated by globalisation (Petras, 2007). Pollock (2014) forensically examines the differences between knowledge of South Asia constructed by the South Asia Institute, Heidelberg and knowledge constructed by scholars in the region. Gamage (2016a) examines the way Buddhist concepts can be used to construct social theory and value-oriented education.

In this paper, in addition to examining Eurocentrism and dominance exercised by metropolitan sociology, the author discusses suggestions made by social scientists from Asia and elsewhere to encourage emerging sociologists in the region to be innovative and creative as well as critical in their search for a sociology practice relevant to South Asian context while moving beyond the received wisdom by way of disciplinary knowledge, perspectives, theories and methods from Western centres of learning, starting from the British colonial period. There are important threads of argument, critique, evaluation and direction that one can discern from the contemporary pluralist sociological discourse for useful leads in reconstructing South Asian sociology. Inspiration can be derived from social scientists who have advanced a critique of Eurocentric social science knowledge and practices that maintain hegemonic relations on one hand and their suggestions for alternative knowledge construction on the other ${ }^{1}$ for the reform and renewal of South Asian sociology. According to Thakur,

'the apparent universals of European modernity refuse to vacate the knowledge corridors that adorn the global academy. This realisation has, 
of necessity, led to the making of a counterdiscourse where the epistemological validity of local/indigenous/folk/endogenous sciences has been put forward' (Thakur, 2015: p. 116).

Even though,

"the path towards an alternate and autonomous universal theory is laden with its own ambivalences, contradictions and silences" (Thakur, 2015: p. 116).

\section{ALTERNATIVE SOCIOLOGY DISCOURSES: CONNELL, SANTOS AND ALATAS}

In this section, key ideas of these three Sociologists who have significantly contributed to the discussions on sociology discourses, are presented as background for the discussion in the latter part of the paper focusing on South Asia.

\section{Connell}

Connell's (2017: p. xi) idea that "the hegemony of metropolitan knowledge does not obliterate all others is noteworthy. Alternative ways of thinking about the world certainly persist" is an important statement. She further asserts that,

"it is helpful to think of social science not as a settled system of concepts, methods and findings, but an interconnected set of intellectual projects that proceed from varied social starting points into an unpredictable future" (Connell, 2007: p. 228).

This is helpful in rethinking Euro-american, Western sociological heritage in South Asia and the alternatives relevant to the contemporary context. Connell's (2007: p. xii) claim that the "colonised and peripheral societies produce social thought about the modern world which has as much intellectual power as metropolitan social thought, and more political relevance" needs to be taken seriously while mapping out ways and means to articulate such social thought cooperatively, comparatively and to disseminate widely in the region and beyond.

In the task of imagining alternative sociologies,

"(i)t is not enough to name the metropole; the job of social science is to analyse it. This is a question of understanding social processes- the institutions, interests and strategies- that generate the catastrophes" (Connell, 2007: p. 216).

(The author would add loss, erasure, domination and dependence.) For example, Connell cites the research institutes and museums that played a key role in the acquisition and centralisation of data from the periphery. The distinction between being a supplier of data for analysis to social scientists in the global north and social scientists in the global south or periphery taking responsibility for analysing the processes as described above is an important distinction to note.

For Connell, a second test for social sciences is to recognise the dynamism that exists in the periphery. The diversity and dynamism existing in the periphery have consequences for the production of knowledge and remaking of social science. The task can range from the social theory of Ashish Nandy in India, who draws on a rich intellectual history, to an Afrikaner intellectuals in South Africa who were cut off from the rich indigenous thought due to settler colonialism (Connell, 2007: p. 213). To undo the erasure created by metropolitan theory and for "reworking the relations between metropole and periphery, it is necessary to make shared learning processes possible" (Connell, 2007: p. 214). She cites the example of subaltern studies where it documented the histories of the oppressed, a task different from mainstream ethnography of non-Western societies. To her, what really matters "is not just the subject-matter of experience' but 'its vector or intentionality, its relation to structures around which a politics of change may form" (Connell, 2007, p. 214). Thus collective loss, a central feature of the history of colonialism, can be a rich source for social science work by intellectuals in the global south.

Connell further believes that there are ways of representing the social in all cultures. By using concepts derived from such representations, indigenous sociology can be constructed (Connell, 2007). An example is the work of Akiwowo based on Yoruba ritual poetry (see Chapter 5: Connell, 2007). Sociologists and anthropologists in South Asia could look at their cultures, cultural practices and their representations in a similar way. They could even adopt critical perspectives on mainstream anthropological representations of South Asian cultures and their notions of the 'social' in different periods.

Connell has expanded and elaborated her views on these topics in her recent publications (2014; 2017). Referring to Hountondji's arguments (1997), Connell writes that,

"the attitude of intellectuals in the periphery is one of 'extraversion', that is, being oriented to sources of authority outside their own society. This is very familiar in academic practice even in a rich peripheral country like Australia" (Connell, 2014: p. 211). 
She discusses how the recent work in six countries have challenged what she calls 'the political economy of knowledge' and initiated an "analysis of the postcolonial periphery as a site of knowledge production" (Connell, 2014: p. 211).

Changing the way metropolitan social science operates in the world requires retooling that can be arduous. Equally arduous is ending the extroversion of social science in the periphery for global dialogue. Connell believes that under the existing political economy of knowledge,

"Professional self-images, personal stocks of knowledge, affiliations, citation practices, publication strategies both of individuals and of publishing houses, grant-getting and practical applications of social science, are all at stake" (Connell, 2007: p. 227).

What Connell calls Southern Theory "is not exactly an indigenous knowledge project, nor primarily a critique of Eurocentrism" (Connell 2017: p. 8). An example she provides is Indian Subaltern Studies. Early issues of this journal were "deeply concerned with the ideas of colonized people, but did not try to reconstruct or assert indigenous understanding from before colonization" (Connell, 2017: p. 9). On the contrary, the "Knowledge generated in the colonial encounter, and in the postcolonial experience of the colonized societies is central to the idea of Southern theory" (Connell, 2017: p. 9).

\section{Santos}

Santos calls for a transition from the Western modernist paradigm to a non-abyssal one to fight injustice and achieve emancipation for the oppressed classes and the socially excluded (Santos, 2014) ${ }^{2}$. He says that,

"The Western-centric abyssal line has historically excluded large segments of populations and ideas from experiencing the world as their own and thus from actively participating in its transformation" (Santos, 2014: p. 240).

He calls to denunciate colonial ontologies from which universal theories of social transformation was derived and invites social scientists to,

"a much larger experience of the world as one's own and a task of transferring the worlds into a more equal and diverse one through epistemologies of the South" (Santos, 2014: p. 240).
However, in order "to understand what is missing and why, we must rely on a form of knowledge that does not reduce reality to what exists" (Santos, 2014: p.157). The form of knowledge that is needed is one "that aspires to an expanded conception of realism that includes suppressed, silenced, or marginalized realities, as well as emergent and imagined realities" (Santos, 2014: p. 157). Santos further asserts that "Once transformed by knowledge-as-emancipation, common sense may be the source of a new rationality" (Santos, 2014: p. 159).

In terms of Sociology Of Absences (SOA's) and emergences, Santos engages in a critique of the Western model of rationality/reason.

"Sociology of absences inquires into the possible presence of other understandings in different regions that were subjected to European historical colonialism and capitalism (Europe included) and into the ways they may be present as empowering resources in the struggle of oppressed social groups against capitalism and colonialism" (Santos, 2014: p. 179).

The objective of SOAs is "to disclose the diversity and multiplicity of social practices and confer credit to them in opposition to the exclusive credibility of hegemonic practices" (Santos, 2014: p. 181). Through sociology of emergences, he proposes a model called 'subaltern cosmopolitan reason' (for details see Chapter 6: Santos, 2014).

There is a "difference between hegemonic form of knowledge that creates order (also creates ignorance e.g. colonialism) and form of knowledge that creates solidarity (i.e. epistemology of seeing). However,

"having been over socialized by a form of knowledge that knows by creating order in nature and society, we cannot easily imagine or practice a form of knowledge that knows by creating solidarity both in nature and in society" (Santos, 2014: p. 156).

Santos proposes three strategies to overcome this problem: 1) the epistemology of absent knowledges, 2) epistemology of absent agents, and 3) revisiting representation and its limits (Santos, 2014: p. 157). The first is based on a,

"premise that social practices are knowledge practices. The practices not based on science, rather than being ignorant practices, are practices of alternative, rival knowledges" (Santos, 2014: p.157). 
In his view, "( $\mathrm{t}$ )here is no a priori reason to favour one form of knowledge against another" (Santos, 2014: p. 157). Santos says,

"Modern science built itself against commonsense which it deemed superficial, illusory, and false. Common sense was the name given to all forms of knowledge that did not meet the epistemological criteria that modern science established for itself” (Santos, 2014: p. 157).

When made by science, common sense "signifies the distinction between objective knowledge and mere opinion or prejudice" (Santos, 2014: pp. 157-158). For Santos, conceptions such as the sociology of absences, the sociology of emergences, ecologies of knowledges and intercultural translation are central to calls for counter hegemonic conceptions of (Western centric) human rights, democracy and socialism. Social scientists need to work through contradictions of their time.

\section{Alatas}

Alatas points out that the call for alternative discourses has been in existence since the $19^{\text {th }}$ century. It is,

"a response to what many Asian and other nonWestern social scientists perceive as the inability of Euro-American social science to constitute a relevant and liberating discourse in the context of Asian, African and Latin American societies" (Alatas, 2006: p. 81).

This problem was exacerbated by the fact that much of social science was assimilated uncritically outside of their countries of origin, among students, lecturers, researchers and planners (Alatas, 2006: p. 81). Therefore, various dimensions of Western social science domination and resulting academic dependence need to "be understood within the context of the relationship between the Asian social sciences and Western social science establishments" (Alatas, 2006: p. 38). Alatas proposes several steps including serious theoretical and empirical research on the problems of academic dependency and academic colonialism, and measures to deal with each dimension of academic dependency and greater interaction among social scientists of the formerly colonised countries or the Third World (Alatas, 2006: p. 74). Critique of Eurocentrism should become an essential part of social science syllabi for "alternative discourses to attain greater currency in teaching and research" (Alatas, 2006: p. 174). Manifestations of Eurocentrism such as the perpetuation of subject-object dichotomy, the projection of Europeans as originators in the foreground, the dominance of European (or American) concepts and categories have to be critically examined. One needs to bring in non-Europeans (and non-Americans) to the discourse, teaching and research. In terms of teaching, most critical reversal needs to happen in the European concepts and theories ${ }^{3}$.

Alatas wants to develop alternative discourses from non-Western, indigenous modes of knowledge and philosophical/epistemological traditions. He states that,

"(t)here are cases of non-Eurocentric, counterOrientalist and autonomous social sciences in Asia but such success cases of alternative discourses in Asia remain on the margins of global social sciences" (Alatas, 2006, p. 19).

Notably, "(i)n many instances they are on the margins of social sciences within Asia itself” (Alatas, 2006: p. 19). He believes that alternative discourses can range from lower to higher levels. The highest level "is achieved with the application of locally-derived theories from within and beyond one's own society to areas outside" (Alatas, 2006: p. 83). The lowest level consists of "cautious application of Western theory to the local situation" (Alatas, 2006: p. 83). Alatas explains several varieties of alternative discourses such as indigenisation, autonomous social science, decolonisation, globalisation, sacralisation of social science, subaltern studies, postcolonial theory, nationalisation of social science, delinking, and deschooling (Alatas, 2006: pp. 83-105).

Several features of alternative discourses as proposed by Alatas in social sciences are mentioned below, as they can be useful for sociologists in South Asia ${ }^{4}$.

1. Their starting point is the critique of Eurocentrism and Orientalism in the social sciences.

2. They raise methodological and epistemological problems relating to the study of society, historiography or the philosophy of history.

3. They are concerned with the analysis of problems presented by the world division of labour in the social sciences, i.e. the Asian social sciences find themselves to be in a state of conformity, imitation and unoriginality.

4. They are committed to the reconstruction of social and historical discourses, which involve the development of concepts, categories and research agenda that are relevant to local/regional conditions.

5. They are committed to raising original problems in social and historical studies. 
6. They recognize all civilizations and cultural practices as sources of ideas for the social sciences.

7. They are not in favour of the rejection of Western social science ideas in toto. (Alatas, 2006: p. 82).

Alatas proposes the use of Meta theory. It is "the study of the underlying structure of social context within which theory emerges" including methodological and logical underpinnings (Alatas, 2006: p. 181). Introduction of non-European (and American) ideas into teaching and textbooks is equally important as is propagating such ideas in popular settings.

\section{CRITIQUEOFSOCIOLOGYANDPOSTCOLONIAL THEORYIPERSPECTIVE}

Postcolonial theory is an emerging body of knowledge by the previously colonised countries contributed by writers located in metropolitan centres mostly with immigrant backgrounds as well as those from the global periphery. Postcolonial theory and postcolonial studies are "a loosely coherent body of writing and thought that critiques and aims to transcend the structures supportive of Western colonialism and its legacies" (Go, 2013, p. 29). These structures are political and economic though one strand of theory emphasises the cultural, ideological and the epistemic. Echoing the calls for a postcolonial sociology by Bhambra (2007) and Magubane (2004), Go asks how postcolonial theory can be relevant to sociology? Go's investigation is based on examining theory and historical sociology. In particular he looks at the work of Fanon and Said. Fanon brought questions of culture and identity to the fore by talking about cultural and psychological dimensions of colonialism. Said "unearthed how epistemic structures representing the Orient (as regressive, static and singular) served to support Western imperialism" (Go, 2013, p. 29, citing Said, 1979).

Postcolonial theory "examines all types of discourses, epistemes, cultural schemes, representations, and ideologies that were part and parcel of Western imperialism- whether embodied in everyday discourse, novels, works of art, scientific tracts, or ethnographies" (Go, 2013: pp. 29-30). It,

“grapples with colonialism's legacies and seeks alternative representations of knowledge that do not fall prey to colonialist knowledge's misrepresentations and epistemic violence....it seeks theories (knowledges), ways of representing the world, and histories that critique rather than authorize or sustain imperialistic ways of knowing" (Go, 2013: p. 31).
Postcolonial theory "helps to disclose sociology's Orientalism, Eurocentric universalism, imperial repression, and Enlightenment scientism" (Go, 2013: p. 32). Go defines the first three as metrocentrism. Another criticism he makes is on the analytic bifurcations. Drawing from various postcolonial writers, these are elaborated in his paper. Sociology's orientalism is typified in much of classical sociology. Marx, Weber and Durkheim portrayed non-Western societies as homogeneous essences, static and backward "reserving dynamism, social creativity, energy, and enlightenment for European societies alone" (Go, 2013: p. 32). Classical sociology carried the marks of Eurocentric universalism, e.g. a universal template of development and theoretical categories based upon Europe's experience. Another criticism is Marx's Eurocentric valorization of the working class and neglect of race, gender or cultural difference (Go, 2013: p. 33). The repression of colonial/ imperial history is another criticism.

"Classical sociological works were founded upon attempts to theorize modernity but occluded colonialism or imperialism's potential role in constituting modernity" (Go, 2013: p. 33, citing Amin, 1989).

As Boatca \& Costa (2010) remind, sociology depended upon a suppression of the colonial and imperial dynamics from its toolkit and terminology.

The criticism of sociology on grounds of enlightenment scientiesm is directed at its complicity with Western imperialism. According to this critique, the problem is sociology's existence as the "science of society". Furthermore,

"Sociology is a mode of knowledge that assumes that the social world is fully knowable, that reason alone can arrive at such knowledge, and that the subsequent knowledge is objective and universal and so can be used to control the world (foundationalist, universalist, and scientistic)" (Go, 2013: p. 33).

Sociology is another expression of western thought and hence a part of imperial culture (Go, 2013: p. 33, citing Seth, 2009). Elaborating these points, Go states,

"Sociology's founding faith in reason and progress (that reason can fully know and manipulate the world) and its abstract categories based upon Western assumptions not only parallel but support Western imperialism's hostility towards difference. Sociology's enlightenment assumption of the knowability of all societies 
from the same "objective" standpoint and its search for totalizing, abstract, trans societal theories express an imperialistic will to power that fails to acknowledge the socially-situated, embodied incomplete or "ambivalent" character of all knowledge", (Go, 2013: p. 34, citing Bhabha, 1994; Bhambra, 2007; Connell, 2006; Rodriguez, 2010).

Go says the postmodern-postcolonial critique of Enlightenment rationalism is about "traditional positivism in sociology that aims at prediction, universal covering laws, and assumes absolute independence between social scientific thought and its context" (Go, 2013: p. 35). He describes post-positivist projects undertaken by several sociologists such as the standpoint theory, forms of realism like critical realism, forms of descriptive and historical sociology, and "recent articulations of interpretive social science that align with postcolonial theory's emphasis upon subjectivity and culture" (Go, 2013: p. 35). Importantly, Go agrees with the critics that early European metrocentrism persists and provide some examples. Next he examines how similar problems continue in US historical sociology (Go, 2013: pp. 36-38).

Go is critical of Weber, as he "never considered that capitalism's origins and sustenance may have rested upon imperial accumulation rather than in Protestant beliefs alone" (Go, 2013: p. 36). Similarly, he criticises Marx as he saw "colonialism as a mechanism for expanding capitalism, not as a constitutive force in its very making" (Go, 2013: p. 37, citing Mugubane, 2005; Turner, 1978). In his view, more recent theories show the same problem of subscribing to methodological nationalism and exclude expansive relations across the globe i.e. cutting Europe off from its colonies "as if imperial and colonial history were not also Europe's history" (Go, 2013: p. 37). Such separation or bifurcation, in his view, renders the theoretical categories inadequate (Go, 2013: p. 37).

Go questions Gidden's theory and asks where the boundaries between tribal and class society are and why not conceptualise interrelations? Similarly, he questions Durkheim's mechanical and organic solidarity as they presuppose distinct entities with no interrelations. He questions the belief in Europe as 'the sole originator and agent of history without any contributions from other places or in the absence of relations with others" (Go, 2013: p. 37). Likewise, he is critical of world society and diffusion theories for their Eurocentric universalism exemplified in modernisation theory. The problem in the (diffusion) theory is that diffusion "only happens when it is from the West to the Rest, a unilinear flow. What gets lost are interactive relations" (Go, 2013: p. 38). Thus sociology's Orientalism, Eurocentrism and suppression of imperial history are highly problematic.

Bhambra also mounts a potent critique of sociology and proposes some innovative ideas for a postcolonial sociology. Her work is "centrally concerned with issues of historical sociology, the emergence of modernity, and the disciplinary formation of sociology" (Bhambra, 2016: p. 960$)^{5}$. According to her, conventional understandings of sociology can be criticised on three grounds: (1) substantive, (2) conceptual/methodological and (3) epistemological. She claims that sociology cannot engage with global challenges as it embodies "a particular Euro-centred ideological response to those challenges" (Bhambra, 2016: p. 961). Bhambra sees "sociology both as a system of knowledge oriented to history and as constituted by that history" in terms of epistemological (Bhambra, 2016: p. 963). In her view, concepts in sociology have remained immune to transformation despite the research conducted by generations of feminist scholars. Methods of study in sociology are implicated in significant omissions. Questions have been raised about the tools of the discipline. In addition to being Eurocentric, structures of knowledge production are racialized. She takes issue with the way sociologists work with an ideal type of modernity and how this has been understood methodologically. Even those who subscribe to the idea of multiple modernities tend to carry a belief that modernity was formed in Europe and diffused to other regions. Yet the fact that this diffusion was carried out through colonisation and enslavement goes without acknowledgement (Bhambra, 2016: p. 963). "This way, a dominant Eurocentric focus to the analysis is established, and represented as 'methodologically neutral" (Bhambra, 2016: p. 963).

Much of the critical work that Bhambra discusses emerged "as a consequence of the academy being opened up to diverse demographics, specifically to scholars from social locations not typical of those previously entering higher education" (Bhambra, 2013: p. 965). Formation of new epistemological communities within institutions of learning in the late twentieth century changed our understandings of what is the purpose of knowledge and what constitutes it? (Bhambra, 2016: p. 965). Bhambra argues that this is now at risk due to the marketization of public university.

For Patel, the postcolonial critique is a first step in constructing new sociologies. Postcolonial perspective does not focus on nations and nation-states. It rather focuses on the margins and the subalterns who have been silenced. The focal point is not the coloniser and the native. It is the interrelationship. It confronts the binaries on which sociological and anthropological knowledge has been constructed (Patel, 2006: p. 392). 
According to Connell, postcolonial critique of European thought was publicised through Edward Said's Orientalism. Recent attempts include 'provincialise Europe' and Postkoloniale soziologie (Reuter \& Villa, 2010) and Decolonizing European sociology (Gutierrez Rodriguez, Boatca \& Costa, 2010) (Connell, 2017: p. 8). The latter apply the critique to propose new paths for the social sciences.

"The de-colonial project addressing (and questioning) Latin America involves a potent synthesis of philosophical critique of European knowledge, and validation of indigenous knowledges as alternatives (Lugones, 2009; Mignolo, 2005; Santos, 2014)" (Connell, 2017: p. 8).

Go provides examples of scholarship that offers strategies for meeting the postcolonial challenge, e.g. turning attention to global south, alternative modernities (Go, 2013: pp. 38-39), though he believes that such scholarship may reverse Eurocentrism in the other direction (Go, 2013: p. 39). As a way forward for postcolonial sociology focused on the region, one needs to 'recognize theories premised upon relationalism as opposed to substantialism. Here the basic units and actors of sociological inquiry are substances or essences, as in things, beings or even "systems". They are treated as static agents. "They do the acting and reacting and retain their identity throughout" (Go, 2013: p. 41, citing Emirbayer, 1997: pp. 283-286). "Relationalism insists that connections or interactions between terms or units are constitutive. These relations accordingly assume analytic priority" (Go, 2013: p. 42). As examples of theories suitable for a postcolonial sociology, Go suggests Actor Network Theory and Field Theory (Go, 2013: pp. 4345). He claims that such theories can illuminate existing sociological problems.

Some strategies adopted by postcolonialists include: (1) critique colonial discourse and knowledge, (2) Commonwealth studies in literary studies, (3) Critical readings of canonical Western texts, to reveal how imperialism or colonialism serves as the silent backdrop or enabling condition for the narrative (Go, 2013: p. 31).

"Postcolonial scholars have offered new critical concepts meant to destabilize the assumptions of western imperial culture or disclose the limits of the imperial episteme" (2013: p.31).

Go mentions authors such as Bhabha, Fanon, Chakrabarty and Hall as examples. "The fact that nonwestern colonized peoples have helped to constitute the history of the West and indeed of modernity therefore needs to be reintegrated into our histories and narratives" (Go, 2013: p. 32).
Steinmetz explains four distinct postcolonial approaches that are relevant to sociology: (1) to ask how European ethnography, racism, social ontologies, and other aspects of culture shaped empires? (2) to focus on the ambivalences of the colonizer-colonized relationship and colonial hybridity, (3) to criticize Western knowledge as inadequate for the task of understanding (post) colonized non-Western cultures, e.g. Chakrabarty (2000), and (4) concerns imperial 'blowback' or the reflux of colonial culture back into the metropoles (Steinmetz, 2014: pp. 93-94).

Discussing the virtues of postcolonial perspective, Patel argues that "self-reflexivity needs to be extended to sociological/anthropological knowledge produced in ex-colonial countries from orientalist and nationalistindigenous perspectives" (Patel: 2006: p. 393). She further points out that,

" (S)elf reflective sociologies need to break open the binaries on which they were constructed, interrogate the divisions embodied in the construction of knowledge of society, move away from the universalisms of classical theorists of early modernity and assess the many different ways to understand the consequences of this modernity both in terms of social processes and their knowledge systems" (Patel, 2006: p. 393).

Chakrabarty provides a retrospective discussion of the subaltern studies project and its legacy (Chakrabarty, 2015). It is a useful account of the history, challenges and personalities involved in the project.

\section{SOUTH ASIAN SOCIOLOGISTS ON ALTERNATIVE SOCIOLOGIES}

Sociologists from the region, such as Nazarul Islam (2004), have noted a crisis of sociology in the region and globally, while making suggestions for reforms. Others have made suggestions for an autonomous or indigenous sociology in India and other South Asian countries. Some deal with epistemological or knowledge construction issues in the field from a postcolonial perspective. In the following sections, these suggestions are outlined to provide a feel for the reader about the regional thinking on this subject ${ }^{6}$.

\section{Indigenous sociology: Alatas, Thakur and Patel}

According to Alatas, in the task of addressing academic dependency, there's not much to do at the structural or material level but much at the intellectual or theoretical level by constructing alternative discourses "that present themselves as alternatives to theory regarded as the 
Orientalist or Eurocentric social sciences of the North, on which the Southern social sciences are dependent" (Alatas, 2010: p. 139). Here the,

"Alternative is being defined as that which is relevant to its surroundings- is creative, nonimitative and original, non-essentialist, counterEurocentric, autonomous from the state and autonomous from other national or transnational groupings" (Alatas, 2006: pp. 82-83) ${ }^{7}$.

He believes that "non-Western knowledge traditions and cultural practices should all be considered potential sources of social science theories and concepts" (Alatas, 2010: p. 139). It has the potential to "decrease academic dependence on the world social science powers" (Alatas, 2010: p. 139).

The (i)ndigenization project not only acknowledges but also insists "that all cultures, civilizations, and historical experiences must be regarded as sources of ideas" (Alatas, 2010: p. 142). He contends that "without indigenization projects throughout the world, it is one set of indigenous (Western) discourses that dominate" (Alatas, 2010: p. 143) ${ }^{8}$. Indigenisation process requires a "turn to indigenous philosophies, epistemologies, histories, art and other modes of knowledge, which can all be potential sources of social science theories and concepts" (Alatas, 2006: p. 86). Though indigenization of knowledge recognises all cultures, civilizations and historical experiences as sources of ideas, it does not discard Western social sciences (Alatas, 2006: p. 87) ${ }^{9}$.

The question of indigeneity has been a recurrent theme in Indian sociology.

"Some sociologists in India have consistently emphasised the need for 'indigenising' social sciences in the face of uncritical acceptance and application of concepts and theories derived from the West" (Thakur, 2015: p.110).

He notes that the,

"discourse effortlessly shift from the need to confront colonial dependencies with the cultural confidence of high nationalism to the current imperative to create a collective political language and the intellectual infrastructure of the global South" (Thakur, 2015: p. 117).

While "there is general celebration of the antiEuropean and anti-colonial tenor of the early nationalist sociology", there is also "the thorough-going critique of the nationalist strategy for its hegemonic role in relation to its internal others" (Thakur, 2015: p. 117).
According to Patel, the indigenous perspectives or alternative knowledge frames to understand Indian social reality that emerged from the critique of colonization and the development of nationalist thought incorporated two broad perspectives. The first is found in the work of D. P. Mukerjee whose argument was that sociology needs to be culture-specific, representing theories that capture particular experiences (Patel, 2006: p. 389). He called for new methodological and epistemological precepts to assess such experiences. Secondly, his approach was superseded by the new indigenous approach developed by M. N. Srinivas who used social anthropological tools to formulate an indigenous theory of social change. His 'field view' replaced the Orientalist bias towards scriptures as sources. Compared to other Indian sociologists who perceived modernity and 'captive mind' as the major fault line in Indian sociology, Srinivas's indigenous theory of change was based on the caste system. His theory privileged the role played by 'insider' over the 'outsider' (Patel, 2006: pp. 389-390).

\section{For Srinivas,}

"a sociologist/anthropologist studying his or her own society, does it very well, being well versed in its language, culture and in the Indian context, its diversity" (Patel, 2006: p. 390).

In his theory and methodology the village acquired significance. "A localized setting became representative of a whole nation, a whole society. The microcosm came to represent the macrocosm" (Patel, 2006: p. 390). Patel opines that Srinivas's was a functionalist approach. However, it failed to make a historical assessment of colonialism and post-independent processes that were structuring new forms of inequalities and redefining old forms. Nor could it critically evaluate received theories and concepts and understand its relation with the project of modernity.

Sociologists and anthropologists who followed Srinivas argued that national community organized in terms of caste-represented nation-state. Inequalities were to be studied in terms of caste rather than class. "Caste was perceived as a system that unified the whole nation, best understood when it is studied in the village" (Patel, 2006: p. 390). Patel, however, claims that Srinivas's indigenous sociology failed to recognize that the so-called 'traditional' features of Indian society were attributes constructed by modernity to mask Indian society's modern and colonial character. Thus, despite the fact that India was modern, social anthropologists studied tradition instead of modernity. This is a proposition that has applicability to the South Asian region over and beyond Indian anthropology. 
Thakur wants to show "the centrality of the indigeneity question in the discourses and contemporary practices of the discipline" (Thakur, 2015: p. 111) by drawing upon Radhakamal Mukerjee's voluminous work. He invokes Mukherjee because long before radical academics ventured into constructing postcolonial theory, he was well ahead of his times as one who "questioned the historical privileging of Europe in the context of modern social sciences" (Thakur, 2015: p. 111). Mukherjee not only "wanted to use Indian principles to create a universal sociological theory" (Thakur, 2015: p.114) but he "conceived of the alternative frameworks of understanding human action, meanings and purposes" (Thakur, 2015: p. 111) ${ }^{10}$.

Patel (2006: p. 391) cautions as to whether the use of the indigenous perspective solves the problems inherited through the colonial construction of knowledge and whether it can provide an alternative epistemic basis for the reconstruction of sociology knowledge? Rosa, who critically reviewed several publications on epistemologies of the South, believes that the global south is,

"yet to establish a conversation of grandeurs and principles of equivalence that would allow for mutual recognition among the diverse initiatives presented unlike that which has been established for theories of modernity" (Rosa, 2014: p.13).

For her "Social sciences of the periphery do not all share the same basic principles" (Rosa, 2014: p. 10). Her contention is that 'the theories in question are more "social thought' than they are sociology sensu stricto, they are not limited to a specific epistemological scope" (Rosa, 2014: p. 10). Notwithstanding these reservations, it is important for the South Asian sociologists to consider the possibilities available in critical, creative and constructive spaces for alternative sociology knowledge.

An example of how to do indigenous social science work with relevance to global South/South Asia is provided by Gunaratne (2010) in relation to the communications field. He argues that the impetus for deWesternizing communications science must come from the scholars in the non-West:

"Rather than being passive participants, they should not only re-read their classical literature to document non-Western contributions to the traditions of communication arts (i.e. rhetoric, semiotics, phenomenology and critical studies) but also become active agents of change in the third wave of systems theory (within the communication science tradition of cybernetics) by metatheorizing and critiquing the axio-logical, epistemological and ontological dimensions of existing theories, both Western and non-Western" (Gunaratne, 2010: p. 486).

For this task, he recommends several steps:

1. Digging into the axial philosophies and philosophers, and exploring the indigenous literature for identity ideas that could bloom into communication models and paradigms.

2. Creating new comprehensive theories aligned to the third wave of systems theories or complexity science in any of the three forms: empirical- analytical, cultural-critical or historical-hermeneutical.

3. Initiating peer-reviewed journals, preferably with free online access, and university-supported book publishing outside the oligopolistic social science centers of the West.

4. Writing textbooks in English and major regional languages (like Chinese, Malay/Indonesian, Hindi/ Urdu) highlighting the social thought of non-Western scholars aimed at regional groups (e.g. ASEAN, SAARC) or the whole non-West (Gunaratne, 2010: p. 486).

In the case of Sri Lanka, there have been very few attempts by sociologists to construct an indigenous Sri Lankan sociology following postcolonial theory, indigenous sociology or Southern Theory. For that matter, work critical of Eurocentrism and American bias in Sociological theory is even rare. Sociologists and anthropologists who should be contributing to an indigenous sociology in the country are in fact reproducing and applying conventional metropolitan sociology in their research while translating the same in their teachings using the mother tongue. Early efforts by anthropologist cum Sinhala scholar Nandasena Rathnapala did resonate with some undergraduates. However, they did not yield wider acceptance from the sociology community in the country primarily as the methods he employed in research and data collection were considered to be unconventional and problematic. Even his anthropological and sociological writing appeared rather descriptive than analytical. Yet, popular media provided regular publicity to his work, e.g. participant observations of beggars. Other than this, there are only a few examples available of substantive critique of standard anthropology and/or sociology work such as by Perera $(2014 ; 2017)$ and Goonatilake (2001). The latter employs Buddhist approach and concepts to critically examine four well-known anthropologists and their work 
on Sri Lanka. Ranaweera Banda's work (2013) includes a critique of development as knowledge and practice along with rural responses from Denagama- the location of his study. It is a work on knowledge production.

"He describes how development as a knowledge and practice is promulgated and promoted by international development experts, local elites and local bureaucrats" (Frerks, 2015).

Banda has shown how development as an external force penetrates into a community from outside with powerful ideologies (Frerks, 2015). Frerks believes that "there is enough scope and reason to critically deconstruct the development enterprise and its associated discourses" in Sri Lanka (Frerks, 2015).

Following these suggestions South Asian sociologists can examine with a deep sense of interest and obligation the locally based 'narratives' around which South Asian knowledge systems have been organised, including, for example, in textual and oral repositories for a fresh sociological imagination. It is important to identify, expand, compare and apply 'themes' from such repositories that can be used for analysis of issues in contemporary society and its manifold relations with the metropole or the global north. The author would extend this to include the relations South Asian sociology has with those in the global South itself. As Connell has pointed out, it is "possible to conceive of networks of cooperation in the social sciences that run around and across the periphery" (Connell, 2007: p. 228). Though the key difficulty here is finding non-metropolitan bases of cultural authority (Connell, 2007: pp. 227-228), it may be possible to overcome this difficulty if South Asian intellectual traditions and their cultural sources are looked at without the disciplinary blinkers inherited from colonial social sciences. Recent work, such as Pathak \& Kumar (2018) on Modern South Asian thinkers, can be of help for such work.

\section{Pluralising sociology/social anthropology to counter Eurocentrism/Universalism}

This is another argument advanced by these critics in order to move beyond Western sociology and embrace the diversity reflected in global sociology. For instance, Patel emphasizes the need to, "historicize and spatialize these diverse sociological traditions through the construction of new theories and methodologies in reference to a world divided by inequalities and its knowledge systems. It implies a need to change the vocabulary of sociology from its peculiar particularistic variant disguising itself in universal principles to a comparative internationalist position" (Patel, 2006: p. 393).
According to her, for plural sociologies to emerge, one needs to decouple the binaries constructed during the colonial-modernist project and reinforced under globalisation (Patel, 2006). Along with other sociologists, she has elaborated this theme in the ISA Handbook of Diverse Sociological Traditions (2010). Thus, one needs "to locate the varied networks that bind the village(s) to regions, the country and the global system, which colonialism inaugurated and which contemporary processes are enhancing" (Patel, 2006: p. 391). In enlarging the sociological imagination to incorporate these networks, she wants to focus on three networks- labour, capital and communication- as they bind localities such as villages to the global system. Such a shift in the focus and imagination can change the "entire set of principles that make the frame of reference for contemporary sociological/anthropological theory" (Patel, 2006: p. 391).

Reviewing the trends and gaps in the practice of sociology undernew globalisationand the reconfigurations occurring at multiple 'local' levels between 1993 and 2010 in India, Vasavi (2011: p. 400) "calls for pluralising the SOI so as to energise the discipline, the production of its literature, and its pedagogies for varied contexts and audiences". In this task, it is important to consider the body of theoretical literature as well as the contributions of earlier scholars to identify varied practices in various contexts. While emphasising the need to pluralise sociology and social anthropology in India, she outlines the challenges faced in this task and the necessary steps (Vasavi, 2011: pp. 412-420).

The challenges relate to representation of complexities, trends and variations in the nation; locating specificities of local cultural categories, premises and suppositions within broader theoretical paradigms that allow for comparison; generating a new body of sociological literature leading to new books, texts and pedagogies; and bridging divides between socio-anthropological scholarship, metropolitan and regional institutions, English versus Indian language texts, and differences between scholarship for local or international use (Vasavi, 2011: pp. 412-13). This implies consideration of how Indian sociology "can represent the realities of the nation and its myriad cultures and their complexity, while also being amenable to international comparison" (Vasavi, 2011: p. 413). In her view, regional variations need to be better represented and under-studied regions ...need to be better studied and represented (Vasavi, 2011: p. 413). The steps required for pluralising sociology in India include the following:

1. Extension of research to new sites, arenas and themes, including 'studies of the vicinity', and those 
reflecting the current predicament of nation and its people.

2. New methodologies for research.

3. Writings in Indian languages and integrating translations of sociological work conducted in English.

4. Collaboration across institutions and scholars.

Vasavi (2011: p. 414) also suggests to engage with new realities of different forms of culture that have new logic and typologies under conditions of globalisation. She proposes several contemporary topics for study including strategies of survival in the face of sharp erosion of livelihoods, media and consumerism, contradictions in the political mobilisation, the individualisation of economic and social disadvantages; the creation of new risk-bearing subjects in the market-led economy due to the withdrawal of the state; and the new ethnic, regional and religious identities (Vasavi, 2011: p. 415).

Furthermore, it is necessary to incorporate the body of writings in regional languages into the practice of sociology, e.g. Bengali, Malayalam, Marathi, Kannada, and Tamil (Vasavi, 2011: pp. 418-419).

"Indian language writings on socio-cultural issues can enhance the body of social sciences as they can create new perspectives on the study and understanding of established issues, introduce new themes, categories, and ideas (which may not be recognised by English-based social sciences), and generate new theories for understanding Indian societies and cultures" (Vasavi, 2011: p. 420).

"Engaging with such writings may enable sociologists to contribute to the growth of "epistemologies of the South" (Santos, 2007: p. 55) "rather than always being in the shadow of Western-derived theories and categories" (Vasavi, 2011: p. 420) ${ }^{11}$.

One challenge in creating a South Asian sociology is the diversity rather than uniformity of intellectual traditions and sources within South Asia itself. While diversity is presumed to be the basis for the call for pluralising sociology, the question remains as to how far such diversity can enhance or encourage regionally and/or universally applicable concepts, theories and even methodologies?. The academic project undertaken by Connell's book is aimed at "constructing an epistemology that takes this diversity into account" (Rosa, 2014: p. 4), including indigenous knowledge systems. While Connell says that in constructing alternative knowledge one should not attempt to construct another hegemony, commenting on Santos's work Rosa says, "in order to deconstruct a hegemonic form, it is necessary to construct another hegemonic form, one populated with the imagination of the colonized as well" (Rosa, 2014: p. 4). The proposal of Santos is to use the dialogue of differences or ecology of knowledges- a non-hierarchical point in common between scientific knowledge of the North and traditional knowledge of the South (Rosa, 2014: p. 4). The sites of such epistemologies identified by Santos (2014) are "popular, secular, proletarian, peasant and indigenous". Here it is important to emphasise that,

"The call for alternative discourses in Asian social sciences is not to suggest that Asia is a culturally homogeneous entity and that there could be a peculiarly Asian brand of social science. What it does suggest, however is that the social sciences, like other forms of knowledge, is social and historical in nature" (Alatas, 2010: p. 151).

\section{CONCLUSION}

Some sociologists who adopt a postcolonial perspective live and work in metropolitan universities in the U. S., Europe and countries like Australia. Many of them or their children have been immigrants to these countries. The expansion of university education in the UK, for example, changed demographics in higher education leading to the emergence of critical sociologists who tended to read classical and contemporary sociology taught in higher education institutions in such countries with a different perspective, e.g. postcolonial, marginalised or minority, feminist. Thus, there is a body of knowledge constructed by critical sociologists who have advanced different understandings of not only the emergence of sociology but also the applicability of associated concepts, theories and methods to contemporary issues and contexts. This paper examined these critical imaginations and arguments that have been advanced for a new sociological imagination, some applicable to both global north and south (e.g. connected sociologies by Bhambra) and others as applicable to the global south such as postcolonial sociology, Southern Theory (Connell), alternative sociology (Alatas), pluralist sociology (Patel) and indigenous sociology (e.g. relational sociology by Go, connected sociologies by Bhambra).

While these developments take place elsewhere, one has to ask whether there have emerged similar critical epistemic communities within South Asia's public universities as the demographics changed with the onset of mass education after countries in the region gained political independence. One needs to critically examine 
why there are no such communities or groups like those who contributed to Subaltern Studies in India? In the social sciences, instead of such emergences, what is witnessed is the continuation of academic dependency and captive minds indoctrinated by metropolitan disciplinary knowledge inherited from the Anglo-European imperial centres that colonised countries of South Asia combined with North-American influences (for a case study of Sri Lanka, see Gamage, 2016b; Seneviratne, 2018). The consultancy work of the region's sociologists affiliated with public universities for international agencies, as shown by Ranaweera Banda in Sri Lanka, work against such emergences as is the continuation of a 'colonial mindset' in modern forms whose qualities include deficiency, subservience, powerlessness, imitation, uncritical acceptance of superiority and the absence of creativity. In such a context, conceptual and methodological transformations in sociology are highly unlikely without collective awakening to this need informed by critical re-imaginations of the 'discipline' including its provinciality and relevance.

In the task of re-imagining sociology, following Connell, one needs to recognise the "long-lasting pattern of inequality in power, wealth and cultural influence that grew historically out of European and North American imperialism" (Connell, 2007: p. 212) and identify different situations of metropole and periphery within South Asia. Theories that do not recognise this pattern and the diversities fail the test of realism. Since material interests of intellectual workers tie them to the metropole, Connell advocates that the lateral links among intellectual workers need a non-material rationale (Connell, 2007: p. 229).

"In the era of neoliberal globalization, the question is now what kind of intelligentsia is sustainable in postcolonial settings that has any kind of autonomy from the powerful northerncentred economy of knowledge" (Connell, 2014: p. 214).

Connell's recent thinking on the role of intellectuals in the global south (Connell, 2018) can be a guide for sociologists.

Before examining different kinds of academic relationships between South Asia and the metropole in Europe and North America, it is important to recognise the unequal and long lasting pattern of inequality in terms of wealth, power and cultural influence that existed, is existing, and that may exist in the future and their implications for intellectual tasks such as sociological imaginations, practices and applications. This is a concrete task that the region's sociologists can pursue as an immediate project with contextual relevance taking the clues from the region's sociologists such as Sabir (2010; 2016), Patel (2006; 2010 a \& b) and Thakur (2015).

A question arising from the foregoing discussion is whether one has to delink or distance ourselves from Western social sciences in order to create an indigenous or pluralist sociology?. Consensus seems to be that rather than wholesale delinking, selective utilisation of Western concepts, theories and methods in comparison to indigenous concepts, theories and methods extracted from local traditions, philosophies, religions, etc., should be the way forward (Alatas, 2006; 2010; Connell, 2007; 2014). Otherwise, exercises toward building indigenous or plural sociology could end up being nativistic. Furthermore,

"(R)adical epistemological projects like
indigenous sociology can internally be a
conservative political project. Such projects have
been shown to be exclusionary towards its internal
others. Similarly, the primacy of indigenous
cultural materials may privilege the outlook of a
narrow group" (Thakur, 2015: p. 120).

For example, in India, "the nationalist sociology silenced various regional traditions, and projected the dominant high-caste, middle-class Brahmanical view at the national level" (Thakur, 2015: p. 117).

Referring to the demarcation between the global north and south, Santos states that the global lines are moving again in the opposite direction "in such a way that the other side of the line seems to be expanding while this side of the line (i.e. in the global north) is shrinking" (Santos, 2014: p. 125). In his view, post abyssal thinking requires a radical break from the modern Western ways of thinking and acting and thinking from the perspective of the other side of the line. He explains the changes occurring on this side of the line including the fact that the abyssal thinking will go on reproducing. Santos nominates several features of post abyssal thinking such as "learning from the South through an epistemology of the South" and "situating our perspective on the social experience of the other side of the line" (Santos, 2014: p. 134). Gandhi is mentioned as one who consistently thought and acted in non-abyssal terms. Epistemologies of the South reflect a paradigmic transition "as ways of knowing born in the struggles against capitalism, colonialism and patriarchy" (Santos, 2014: p. 238). The break in epistemology proposed by him "is premised upon a break with the type of reason that lies at the core of hegemonic Western thinking" (Santos, 2014: p. 163). 
Given the ideas, criticisms and suggestions made by various thinkers as delineated in preceding sections, one can focus further on the possibilities for postcolonial sociology for South Asia. For example, it can be examined how modernism continues as a dominant paradigm in sociology, colonial legacies and alternative knowledge, the manner Eurocentric universalism, scientism and positivism persist in South Asian sociology, how concepts have become immune to transformation and discover new critical concepts and the forms in which sociologists in the region maintain extraversion toward metropolitan sociology.

Thinking beyond the imitative and reproductive mode in teaching sociology requires critical, creative and 'out of the box' thinking and reflection by sociologists in the region by posing difficult questions and looking for answers from own contexts and scholarly traditions. In this task, they need to get involved with other social scientists and humanities scholars who are versed in the local traditions of scholarship- though not called sociology scholarship per se- and enter into collaborative work in terms of teaching, reflective practice, research and publications. Attempts to distinguish themselves by using the language and terminology of sociology as special or the supposedly superior, historical origins of the discipline need to be abandoned in their interactions with other social scientists and humanities scholars or even indigenous literati who are not formally trained in sociology/social science methodologies derived from metropolitan centres. One needs to look at age-old literary practices with a fresh set of eyes and re-discover the value of the wisdom contained in them for contemporary uses and futuristic enterprises. One needs to move beyond the old fashioned formal disciplinary discourse of sociology derived from Euro-American, Western heritage toward an unknown, undiscovered social, religious, political, and economic thought that exists in the sub-layers of societies in the region.

If sociology is perceived as a science or a pseudo science that is designed to discover 'objective' truths or realities by using a rigorous methodology in the empirical tradition, there are very little deviations one can achieve whether the research is conducted in South Asia, Europe or America. Therefore, sociologists in South Asia and elsewhere may need to think beyond this orientation to research by embracing critical, interpretivist and other approaches while re-discovering approaches from their own historical, philosophical, religious and literary traditions to the study of society, culture, human behaviour, interactions and social problems. The work reviewed here can assist them in this task. To conclude, the author quotes from Connell:
"The structural differences between metropole and periphery, and between rich and poor in the periphery, remain important. They still shape the formation of intelligentsias, their resources and the conditions of their work. The multiple knowledge projects that arise in the world social order are also shaped by global structures. But they are in an important sense open-ended, and can be shared by intellectual workers who have different structural positions. In that sense, despite all the modern mechanisms of hightechnology surveillance and cultural control, a far more democratic agenda for knowledge formation on a world scale has now become possible. It is up to us now to find ways of educating, resourcing and sustaining the workforces who can make it real" (Connell, 2014: p. 219).

\section{END NOTES}

1. Connell (2007: p. 226) argues that mainstream sociology -which has "profound insights, well-honed methods, well-defined concepts and lots of skilled practitioners - is an ethno-sociology of metropolitan society, though not recognized as such". It poses a problem about "the truthfulness of arguments framed as universal generalisations" (Connell, 2007: p. 226).

2. Santos believes that his work and that of Comaroff \& Comaroff (2012) converge-though the latter focus on Africa as an example. Similar convergence exists with the work of Corinne Kumar (2007; 2012; 2013) also.

3. Alatas (2006: pp.179-180) critically discusses the use of religion in social sciences in terms of Western categories such as sacred and profane, secular non secular. He says that the present practice is to foreground comparison of other religions with Christianity.

4. Contrary to Rosa's view, Alatas (2010: p. 139) does not think that the 'discourse on the state of social sciences in the Third World' arise from an intellectual movement'. Rather it arises from a diverse group of scholars and activists.

5. Bhambra's work is informed by scholars in fields such as postcolonial and decolonial studies, e.g., Homi Bhabha, Dipesh Chakrabarty, Stuart Hall, Walter Mignolo, Edward Said and Gayatri Spivak.

6. According to Islam, critically engaging with sociological theory from Bangladesh or the South is extremely difficult due to the lack of good library 
facilities or support for purely academic activities (S. A. Islam, 2006). However, other sociologists believe this should not be an issue.

7. Alatas believes that "alternative discourses could be advocated for Western social science itself" (Alatas, 2006: p. 83).

8. An example of alternative discourses in the Asian context that Alatas outlines is the call for Sinicisation of Social Sciences in China.

9. "Western social sciences are also indigenous" (Alatas, 2006: p. 87).

10. On sociology as a universal Social Science focusing on the work of Mukherjee, indigenieity etc. (see Thakur, 2015: pp. 120-122).

11.One such text is a recent volume of translations from Kannada on contemporary social and cultural issues (Vasavi, 2011). Such writings can enable sociologists to overcome limitations in English-based sociology.

\section{REFERENCES}

Alatas, S. F. (2006) Alternative Discourses in Asian Social Science: Responses to Eurocentrism, New Delhi: Sage.

Alatas, S. F. (2010) The Definition and Types of Alternative Discourses, In Burawoy, M. Chang, M-K. and Fei-yu, M. (Eds.) Facing an Unequal World: Challenges for a Global Sociology (2) Conference Proceedings. Taiwan: Institute of Sociology, Academia Sinica \& Council of National Associations of the International Sociological Association [Online] Available from http://www.ios.sinica.edu.tw/cna/download/proceedings/00. Copyright.pdf [Accessed: $24^{\text {th }}$ June 2016].

Amin, S. (1989) Eurocentrism, New York: Monthly Review Press.

Bhabha, H. K. (1994) The location of culture, London: Routledge.

Bhambra, G. K. (2007) Sociology and Post colonialism: Another 'Missing' Revolution, Sociology. 41(5), pp: 871-884. DOI: https://doi.org/10.1177/0038038507080442

Bhambra, G. K. (2016) Postcolonial Reflections on Sociology, Sociology, 50(5), pp: 960-966.

DOI: https://doi.org/10.1177/0038038516647683

Boatcâ, M. and Costa, S. (2010) Postcolonial sociology: a research agenda, In Rodríguez,G. E., Boatcâ, E and Costa, S.
(Eds.) Decolonizing European sociology: Transdisciplinary approaches, Burlington: Ashgate.

Chakrabarty, D. (2015) Subaltern Studies in Retrospect and Remiscence, South Asia: Journal of South Asian Studies, 38(1), pp: 10-18.

DOI: https://doi.org/10.1080/00856401.2014.977421

Commeroff, J. and Comeroff, J. L. (2012) Theory from the South: Or, how Euro-America is evolving toward Africa., Anthropological Forum: A Journal of Social Anthropology and Comparative Sociology, 22(2), pp: 113-131.

DOI: https://doi.org/10.1080/00664677.2012.694169

Connell, R. (2018) Intellectuals and the Global South, Social Affairs, Fall 1(9), pp: 1-13 [Online] Available from: https://socialaffairsjournal.com/images/Journal_Downloads/ Archives/2018_Fall/1_Raewyn_Connel1_SAJ1_9_. pdf?type=file [Accessed: $19^{\text {th }}$ December 2018].

Connell, R. (2014) Using Southern Theory: Decolonizing Social Thought in Theory, Research and Application, Planning Theory, 13(2), pp: 210-223.

DOI: https://doi.org/10.1177/1473095213499216

Connell, R. (2007) Southern Theory: the Global Dynamics of Knowledge in Social Science, Crows Nest: Allen \& Unwin.

Connell, R. (2017) Southern Theory and World Universities, Higher Education Research and Development, 36(1), pp: 4-15. DOI: https://doi.org/10.1080/07294360.2017.1252311

Connell, R. (2006) Northern theory: The political geography of general social theory, Theory and Society, 35(2), pp: 237-264.

DOI: https://doi.org/10.1007/s11186-006-9004-y

Frerks, G. (2015) Sri Lanka Studies: a Discursive Approach to Development and Conflict, Social Sciences and Humanities Review, 2(2), Matara: University of Ruhuna [Online] Available from http://www.hss.ruh.ac.lk/ejournal/publications/volume02/studies.pdf [Accessed: $18^{\text {th }}$ May 2017].

Gamage, S. (2016a) A Buddhist Approach to Knowledge Construction, Postcolonial Directions in Education, 5(1), pp: 83109.

Gamage, S. (2016b) Academic Dependency on Western Disciplinary Knowledge and Captive Mind among South Asian Sociologists: A Critique, Social Affairs: A Journal for the Social Sciences, Fall 1(5), pp: 1-12.

Go, J. (2007) Sociology and Postcolonialsim: Another 'Missing Revolution?, Sociology, 41(5), pp: 871-884.

DOI: https://doi.org/10.1177/0038038507080442

Go, J. (2016) Globalizing Sociology, Turning South, Perspectival Realism and the Southern Standpoint, Sociologica, 2, May-August. 
Go, J. (2013) For a Postcolonial Sociology, Theory and Society, 42(1), pp: 25-55 [Online] Available from https://link.springer. com/article/10.1007/s11186-012-9184-6 [Accessed: 23 ${ }^{\text {rd }}$ January 2018].

Goonatilake, S. (2001) Anthropologizing Sri Lanka: A Eurocentric Misadventure, Bloomington and Indianapolis: Indiana University Press.

Gunaratne, S. A. (2010) De-westernizing Communication/ Social Sciences Research: Opportunities and Limitations, Media, Culture and Society, (32), pp: 473-500.

Hountondji, P. J (Ed.) (1997) Endogenous Knowledge: Research Trials, Dakar: Codesria.

Islam, N. (2004) Sociology in the $21^{\text {st }}$ Century: Facing a Dead End, Bangladesh e-Journal of Sociology, 1(2) July [Online] Available from http:/www.bangladeshsociology.org/ Bangladesh\%20e-Journal\%20of\%20Sociology.htm [Accessed: $20^{\text {th }}$ November 2016].

Islam, S. A. (2006) Book review, Bangladesh e-Journal of Sociology, 3(2), pp: 90-93 [Online] Available from http://www. bangladeshsociology.org/Bangladesh\%20e-Journal\%20of\%20 Sociology.htm [Accessed: $25^{\text {th }}$ November 2016].

Magubane, Z. (2004) Bringing the empire home: Race, class, and gender in Britain and colonial South Africa, Chicago: University of Chicago Press.

Patel, S. (2006) Beyond Binaries: A Case for Self-Reflexive Sociologies, Current Sociology, 54(3), pp: 381-395.

DOI: https://doi.org/10.1177/0011392106063187c

Patel, S. (Ed) (2010a) Introduction: Diversities of Sociological Traditions, The ISA handbook-Diverse Sociological Traditions, Los Angeles: Sage.

DOI: https://doi.org/10.1007/978-3-642-15603-8_1

Patel, S. (2010b) At Crossroads: Sociology in India, In Patel, S. (Ed) Diversities of Sociological Traditions, The ISA handbook -Diverse Sociological Tradition, Los Angeles: Sage.

DOI: https://doi.org/10.4135/9781446221396.n24

Pathak, D. N. and Kumar, S. (Eds) (2018) Modern South Asian Thinkers, New Delhi: Sage.

Perera, S. (2014) Notes from an Anthropological Wilderness: A critical self-assessment of Sri Lankan 'Anthropology', Blue Moon Blogpost [Online] Available from: http://sasperera. blogspot.com/2014/04/notesfrom-anthropological-wilderness. html [Accessed: 22 ${ }^{\text {nd }}$ November 2014].
Perera, S. (2017) Reclaiming Social Sciences and Humanities: Notes from South Asia, Keynote Address, Ground Views [Online] Available from: https://groundviews.org/2017/12/20/ reclaiming-social sciences-and-humanities-notes-from-southasia/ [Accessed: 03 ${ }^{\text {rd }}$ September 2018].

Petras, J. (2007) Globalization: A Critical Analysis, Journal of Contemporary Asia, 29(10), pp: 3-37.

Pollock, S. (2014) What is South Asian Knowledge Good For?, South Asia Institute Papers, Issue 1, Heidelberg: South Asia Institute, Heidelberg University [Online] Available from: http:// www.columbia.edu/cu/mesaas/faculty/directory/pollock pub/What $\% 20$ is $\% 20$ South $\% 20$ Asian $\% 20$ Knowledge $\% 20$ Good\%20for.pdf [Accessed: 03 ${ }^{\text {rd }}$ September2018].

Ranaweera Banda, R. M. (2013)Transnational Culture and Expert Knowledge: Responses from a Rural Community in Sri Lanka, Colombo: K. S. U. Graphic (Pvt Ltd).

Rodriguez,G. E. (2010) Decolonising postcolonial rhetoric, In E. Gutierrez Rodriguez, M. Boatca \& S. Costa (Eds.) Decolonizing European Sociology: Transdisciplinary Approaches, pp: 50-67, Burlington: Ashgate.

Rosa, M. C. (2014) Theories of the South: Limits and perspectives of an emergent movement in social sciences, Current Sociology [Online] Available at http://journals. sagepub.com/doi/10.1177/0011392114522171 [Accessed: $28^{\text {th }}$ August 2018].

DOI: https://doi.org/10.1177/0011392114522171

Sabir, M. I. (2016) Sociology in Pakistan: Origin and Development 1955-2014, Dissertation for Doctor of Philosophy, France: Universite Paris - Saclay.

Sabir, M. I. (2010) From Academic Dependency to SelfOstracism of Intellectual Labor: the Case of Sociology in Pakistan, Cahiers de la recherche sur l'éducation et les saviours, 9, pp: 73-88 [Online] Available from https://journals. openedition.org/cres/374 [Accessed: $25^{\text {th }}$ February 2016].

Santos, B de S. S. (2014) Epistemologies of the South: Justice Against Epistemicide, Boulder: Paradigm.

Seneviratne, H. L. (2018) Sociology at the University of Ceylon, Social Affairs, 1(7), pp: 105-118 [Online] Available from http://www.socialaffairsjournal.com/Achive/Fall_2017/14_ Sociology_at_the_University_of_Ceylon_HL_Senevirathne SAJ1(8).pdf [Accessed: 04 ${ }^{\text {th }}$ September 2018].

Seth, S. (2009) Historical sociology and postcolonial theory: two strategies for challenging eurocentrism, International 
Political Sociology, 3(3) pp: 334-338.

DOI: https://doi.org/10.1111/j.1749-5687.2009.00079_4.x

Steinmetz, G. (2014) The Sociology of Empires, Colonies, and Postcolonialism, The Annual Review of Sociology, (40), pp: 77103.

DOI: https://doi.org/10.1146/annurev-soc-071913-043131

Thakur, M. (2015) The Politics of Indigenous Social Science: Invoking a Lucknow Sociologist, Society and Culture in South Asia, 1(2), pp: 109-126 [Online] Available from http://journals. sagepub.com/doi/10.1177/2393861715574409 [Accessed: $10^{\text {th }}$ March 2016].

DOI: https://doi.org/10.1177/2393861715574409

Turner, B. S. (1978) Marx and the end of Orientalism, London: George Allen \& Unwin.

Vasavi, A. R. (2011) Pluralising the Sociology in India, Contributions to Indian Sociology, 45(3), pp: 399-426.

DOI: https://doi.org/10.1177/006996671104500304 